\title{
PENINGKATAN PENGETAHUAN DAN KESADARAN TERHADAP KEJADIAN MATA MERAH PADA ANAK
}

\author{
Rani Himayani ${ }^{1}{ }^{*}$, Helmi Ismunandar ${ }^{1)}$, Rasmi Zakiah Oktarlina ${ }^{1)}$, Ari Wahyuni ${ }^{1)}$ \\ 1) Fakultas Kedokteran Universitas Lampung, Bandar Lampung
}

Email : dr.ranihimayani@gmail.com / rani.himayani@fk.unila.ac.id /dr.helmiismunandar@gmail.com

\begin{abstract}
Abstrak
Latar Belakang: Salah satu gangguan yang sering ditemukan pada mata adalah mata merah, yang terjadi ketika pembuluh darah halus di permukaan mata melebar akibat iritasi, peradangan, infeksi, cedera, atau meningkatnya tekanan bola mata. Keluhan mata merah bisa mengenai semua usia. Mata merah umumnya tidak berbahaya, tetapi ada juga mata merah yang memerlukan penanganan segera untuk menghindari kerusakan pada penglihatan terutama pada anak-anak. Tujuan: Peningkatan pengetahuan dan kesadaran baik anak, orangtua dan guru mengenai pentingnya pemeriksaan berkala pada anak agar segera terdeteksi dini apabila ada kelainan mata merah pada anak. Metode : Penyuluhan dan skreening kelainan mata merah pada anak, meliputi pretest dan post test serta pemeriksaan mata oleh ahli. Hasil : Kegiatan diikuti oleh total 50 orang (anak, orangtua serta guru) Taman Kanak Titah Bunda yang dipilih untuk menghadiri penyuluhan dan skreening mata. Berdasarkan data hasil pengamatan pre-test, diketahui sekitar $57 \%$ peserta tidak paham mengenai pengetahuan kelainan mata merah dan $43 \%$ telah mengetahui pengetahuan yang cukup mengenai kelainan mata merah. Setelah dilakukan kegiatan penyuluhan, nilai hasil pengamatan meningkat. Sebagian besar peserta menjadi paham mengenai pengetahuan kelainan mata merah. Setelah dilakukan post-test diperoleh semua peserta sudah paham (100\%) terhadap kelainan mata merah dan bagaimana pencegahan serta pertolongan pertama.
\end{abstract}

\section{Kata kunci : Infeksi, Iritasi, Mata merah, Skreening}

\section{PENDAHULUAN}

Mata merah akibat melebarnya pembuluh darah konjungtiva yang terjadi pada peradangan mata akut, pada kasus konjungtivitis, keratitis atau iridosklitis. Konjungtivitis merupakan kasus yang paling sering terjadi pada anak-anak dan tidak menyebabkan turun penglihatan apabila peradangan tidak mengenai selaput bening mata (kornea). Pembuluh darah superfisial yang melebar pada konjungtivitis. (AAO 2012, Sidarta Ilyas 2014)

Konjungtivitis adalah radang konjungtiva yang dapat disebabkan oleh mikroorganisme (virus, bakteri), iritasi atau reaksi alergi. Gejala konjungtivitis, yaitu mata merah, terasa nyeri, berair, gatal, keluar kotoran (belekan). (FK UI 2017, Sambursky RP dkk 2007). Pada beberapa kasus konjungtivitis mengalami pembengkakkan kelopak mata dikarenakan struktur dibawah kelopak mata memiliki jaringan yang lemah dan membentuk lekukan serta kaya akan pembuluh darah. (Khurana, 2010)

Kasus konjungtivitis virus adalah yang umum ditemukan baik di Indonesia maupun di seluruh dunia, dikarenakan sangat umum dan banyak kasus yang tidak mendapat pengobatan medis karena dapat sembuh sendiri, sehingga data statistik yang akurat tidak tersedia. Pada penelitian di Philadelphia, $62 \%$ dari kasus konjungtivitis penyebabnya adalah virus terutama adenovirus. Sedangkan di Asia Timur, adenovirus dapat diisolasi dari $91,2 \%$ kasus yang didiagnosa keratokonjungtivitis epidemik. Serotipe adenovirus sekitar lebih dari 50 yang telah diidentifikasi dan terbagi menjadi 6 subkelompok. (Lenaerts L dkk 2008, Rajaiya J dkk 2006) 
Konjungtivitis dengan keterlibatan kornea di sebut keratokonjungtivitis, salah satu jenis keratokonjungtivitis epidemik berhubungan dengan adenovirus serotipe 8, 19 and 37. Infeksi virus sering terjadi pada epidemi dalam keluarga, sekolah, kantor, dan organisasi militer.(Kinchington 2005, Sidarta Ilyas 2014)

Faktor risiko predisposisi diantaranya adanya riwayat kedinginan atau infeksi saluran napas bagian atas, higienitas kurang, kontak dengan orang yang terinfeksi dalam lingkungan yang ramai, dan penularan virus dari tangan atau instrument kontak. (Paramdeep Bilkhu, 2013)

Onset konjungtivitis viral secara cepat dapat terjadi pada pasien, namun pada kenyataannya ada periode inkubasi sekitar satu minggu sebelum gejala klinis muncul dan awalnya mengenai satu mata dahulu. (Kaufman HE 2011)

Untuk memberikan pemahaman sekaligus mencegah penularan akibat kasus mata merah pada anak yang bisa menganggu aktivitas anak, maka penulis ingin melakukan penyuluhan mengenai peningkatan pengetahuan dan kesadaran terhadap kejadian mata merah pada anak, dimana penyakit ini dapat dicegah dengan menjaga daya imun tubuh dan sering mencuci tangan.

\section{METODE}

Penyuluhan dan skreening kelainan mata merah pada anak, meliputi pretest dan post test serta pemeriksaan mata oleh ahli. Materi penyuluhan yang diberikan meliputi 1)Definisi mata merah, 2)Konjungtivitis, 3)Terapi, 4)Pencegahan.

Pemeriksaan kelainan mata merah oleh ahli mata untuk skreening dini.

Penilaian yang dilakukan untuk menilai keberhasilan kegiatan ini terdiri dari evaluasi awal, evaluasi proses, dan evaluasi akhir. Evaluasi awal dilakukan dengan memberikan pre-test kepada peserta yang berisi beberapa pertanyaan yang terkait dengan materi yang diberikan. Hasil dari evaluasi ini berupa skor tiap peserta yang merupakan pembagian dari jawaban benar dengan total jumlah pertanyaan dikalikan 100. Evaluasi proses dilakukan dengan melihat tanggapan para orangtua dan anak melalui pertanyaan-pertanyaan yang diajukan ataupun umpan balik yang diberikan dalam diskusi. Evaluasi akhir dilakukan dengan memberikan post-test yang berisi pertanyaan yang sama dengan pre-test. Nilai post-test akan dibandingkan dengan pre-test. Apabila nilai posttest lebih tinggi dibandingkan pre-test maka penyuluhan yang diberikan berhasil meningkatkan pengetahuan mengenai peningkatan pengetahuan dan kesadaran terhadap kejadian mata merah pada anak. Pemeriksaan dilakukan pencatatan dan didata, apabila ada yang mengalami kelainan di bidang mata disarankan ke pelayanan kesehatan untuk mendapatkan terapi awal.

\section{HASIL DAN PEMBAHASAN}

Kegiatan diikuti oleh total 50 orang (anak, orangtua serta guru) Taman Kanak Titah Bunda yang dipilih untuk menghadiri penyuluhan dan skreening mata. Berdasarkan data hasil pengamatan pre-test, diketahui sekitar $57 \%$ peserta tidak paham mengenai pengetahuan kelainan mata merah dan 43\% telah mengetahui pengetahuan yang cukup mengenai kelainan mata merah. Setelah dilakukan kegiatan penyuluhan, nilai hasil pengamatan meningkat. Sebagian besar peserta menjadi paham mengenai pengetahuan kelainan mata merah. Setelah dilakukan post-test diperoleh semua peserta sudah paham (100\%) terhadap kelainan mata merah dan bagaimana pencegahan serta pertolongan pertama.

Hasil skreening kelainan mata untuk kasus mata merah pada anak tidak ditemukan.

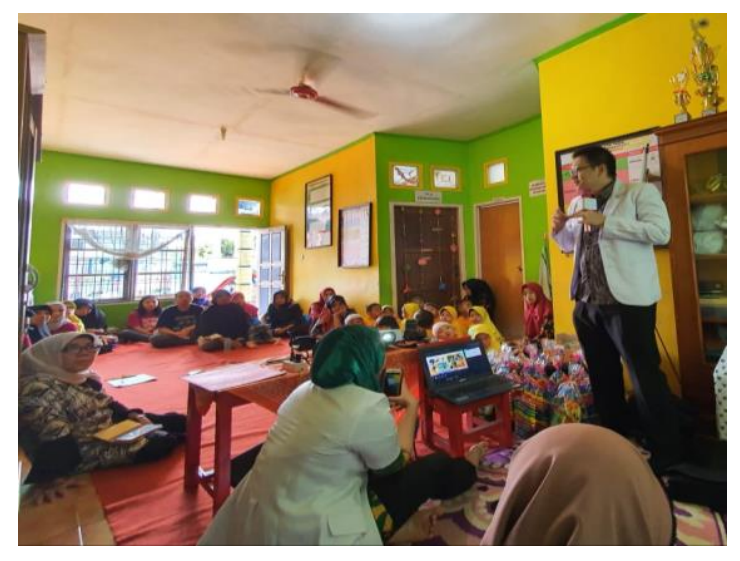

Gambar 1. Penyuluhan dibidang mata oleh tim penyuluhan 


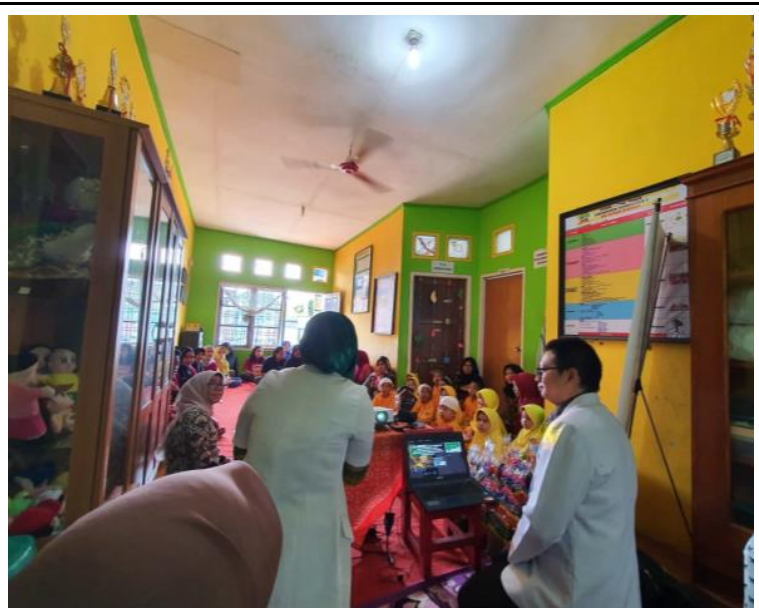

Gambar 2. Diskusi dengan peserta penyuluhan

\section{KESIMPULAN}

Pengabdian ini dapat membantu masyarakat, khususnya anak-anak agar terdeteksi awal apabila terdapat gangguan kesehatan mata sehingga segera mendapat penanganan yang tepat dan memberi masukan ilmu yang bermanfaat dalam dunia medis..

\section{UCAPAN TERIMAKASIH}

Kami ucapkan terima kasih kepada Taman Kanak Titah Bunda atas partisipasinya dalam rangka penyuluhan bidang kesehatan untuk peningkatan pengetahuan kesehatan di bidang mata.

\section{REFERENSI}

1. American Academy of Opthalmology. External Disease and Cornea Section 11. San Fransisco: MD Association; 2006.
2. Ilyas S. Ilmu Penyakit Mata. Jakarta: FakultasKedokteranUniversitas Indonesia. 2014.

3. Buku ajar oftalmologi. Badan Penerbit Fakultas Kedokteran Universitas Indonesia. 2017. Jakarta

4. Sambursky RP, Fram N, Cohen EJ. The prevalence of adenoviral conjunctivitis at the Wills Eye Hospital emergency room. Optometry. 2007; 78:236-9.

5. Khurana AK, editor. Disease of The Conjunctiva. Comprehensive Ophtalmology 4th. New Delhi. 2010.

6. Lenaerts L, De Clercq E, Naesens L. Clinical features and treatment of adenovirus infections. Rev Med Virol. 2008; 18:357- 74.

7. Rajaiya J, Chodosh J. New paradigms in infectious eye disease: adenoviral keratoconjunctivitis. Arch SocEspOftalmol. 2006; 81:493-8.

8. Kinchington PR, Romanowski EG, Gordon YJ. Prospects for adenoviral antivirals. J AntimicrobChemother. 2005; 55:424-9.

9. Paramdeep Bilkhu, Shehzad Naroo, James Wolffsohn. Infectious Conjunctivitis. Ot Cet Continuing Education \& Training. 2013.

10. Kaufman HE. Adenovirus advances: new diagnostic and therapeutic options. CurrOpinOphthalmol. 2011; 22:290-3. 